\title{
Neurophysiological assessment of brachioradial pruritus patients
}

\author{
Avaliação neurofisiológica de pacientes com prurido braquiorradial \\ Luiz Henrique Granja Souza Vieira MILLER', Juliana AKITA', Antonio Carlos Ceribelli MARTELLI², \\ Daniel Rocco KIRCHNER?', Manoel Henrique SALGADO³, José Antonio GARBINO
}

\begin{abstract}
Background: Pruritus is a common complaint in dermatology. Wartenberg, in 1943, associated pruritus with neuropathy, relating it to the "posterior antebrachial cutaneous nerve neuropathy". In 1968, Waisman described patients with frequent pruritus complaints in the upper limb during the summer, which he named "brachioradial summer pruritus". Currently, this pruritus is named brachioradial pruritus (BRP). BRP is characterized by a chronic pruritus, usually localized, with a long duration, and without apparent cutaneous abnormalities. Neurological disorders both from the central and peripheral nervous systems, including multiple sclerosis, are associated with pruritus. Objective: To investigate correlations between symptomatic dermatomes and alterations in the myotomes, as evidenced by electroneuromyography (ENMG). Methods: Forty-six patients with BRP dermatological diagnoses were subjected to upper limb ENMG. Results: Among 46 patients with C5 to C8 dermatomal pruritus, we evaluated 113 symptomatic dermatomal areas. Overall, 39 (85\%) patients had radicular involvement and $28(60 \%)$ had agreement between complaint and the ENMG findings $(p=0.015)$. A total of $80 \%$ of the patients with complaints at C7 and $47 \%$ at C6 had radicular involvement at the same level. Conclusions: Among the patients who presented complaints, 47 and 80\%, respectively, had ENMG alterations in the C6 and C7 myotomes. We conclude that peripheral nervous system involvement is associated with BRP.
\end{abstract}

Keywords: Electromyography; Radiculopathy; Pruritus.

\section{RESUMO}

Antecedentes: 0 prurido constitui queixa frequente e desafiadora na prática dermatológica. 0 primeiro estudo a relacionar prurido com neuropatia foi de Wartenberg, em 1943, que associou à "neuropatia do nervo cutâneo antebraquial posterior”. Em 1968, Waisman descreveu pacientes com queixas recorrentes de prurido em membros superiores no verão, sendo denominado, então, "brachioradial summer pruritus". Atualmente, esse prurido é denominado como prurido braquiorradial (PBR). O PBR é caracterizado por prurido crônico, geralmente bem localizado, de longa duração e sem anormalidades cutâneas aparentes. Doenças neurológicas, tanto centrais, esclerose múltipla ou acidente vascular cerebral como do sistema nervoso periférico, estão associadas a prurido. Objetivo: Investigar os dermátomos sintomáticos pela eletroneuromiografia (ENMG). Métodos: Foram estudados 46 pacientes com diagnóstico dermatológico de PBR com a eletroneuromiografia dos membros superiores. Resultado: Foram avaliados 46 pacientes com queixa dermatológica de C5 a C8 somando 113 áreas dermatoméricas sintomáticas. Observou-se que 39 (85\%) pacientes apresentavam comprometimento radicular, sendo que em 28 (60\%) houve concordância plena entre as queixas e os achados da ENMG ( $p=0,015)$, e que $80 \%$ dos pacientes com queixa em território de C7 e 47\% em C6 apresentavam comprometimento radicular no mesmo nível. Conclusões: As queixas mais frequentes foram as correspondentes aos territórios de C6 e C7, sendo que 47 e $80 \%$, respectivamente, apresentaram alteração na ENMG nesses miótomos. Dessa forma, evidenciou-se correlação entre comprometimento do sistema nervoso periférico (i.e., radicular) com PBR.

Palavras-chave: Eletromiografia; Radiculopatia; Prurido.

${ }^{1}$ Instituto Lauro de Souza Lima, Departamento de Neurofisiologia Clínica, Bauru SP, Brazil.

${ }^{2}$ Instituto Lauro de Souza Lima, Departamento de Dermatologia, Bauru SP, Brazil.

${ }^{3}$ Universidade Estadual Paulista, Faculdade de Engenharia, Engenharia de Produção, Bauru SP, Brazil.

LHGSVM (D) https://orcid.org/0000-0001-8244-3910;JA (DD https://orcid.org/0000-0002-2645-5543;ACCM (iD) https://orcid.org/0000-0002-8162-256X; DRK (iD) https://orcid.org/0000-0001-9229-1148; MHS (iD) https://orcid.org/0000-0003-2571-6366; JAG (iD) https://orcid.org/0000-0002-4042-5797

Correspondence: José Antonio Garbino; Email: ja.garbino@gmail.com.

Conflict of interest: The authors declare no conflict of interest.

Authors' contributions: LHGSVM: literature review, method, clinical anamnesis, electroneuromyography examinations, data collection and writing; JA: method, clinical anamnesis, electroneuromyography examinations and data collection; ACCM: literature review, project design and clinical anamnesis supervision; DRK: method and electroneuromyography examinations supervision; MHS: statistical studies; JAG: project design, method, clinical anamnesis and electroneuromyography examinations supervision and final report.

Received on July 20, 2020; Received in its final form on October 03, 2020; Accepted on November 29, 2020. 


\section{INTRODUCTION}

Among the chronic cutaneous manifestations, pruritus is one of the most challenging in terms of propaedeutic and dermatological treatment. Considering the impact of chronic pruritus $(\mathrm{CP})$ on quality of life, the investigation of its etiology is crucial to define follow-up strategies.

In the first case description in 1943, Wartenberg related the "posterior antebrachial cutaneous nerve neuropathy" to pruritus ${ }^{1,2}$. Waisman, in 1968, described patients with recurrent pruritus complaints, located predominantly in the upper limbs, and occurring in the summer'. In Waisman's study, the brachioradial muscle region was mostly affected and symptoms were described as pruritus, burning, stinging, paresthesia, or localized pain that could be relived with ice. Waisman named this pruritus as "brachioradial summer pruritus", which is currently known as brachioradial pruritus (BRP) ${ }^{4}$.

In 2007, the International Forum for the Study of Itch (IFSI) suggested to use the concept "Chronic Pruritus in the Absence of Skin Diseases" in order to avoid ambiguity with terms such as "essential pruritus". This definition is used to designate systemic, neurological, psychogenic, and mixed conditions that can be present along with chronic pruritus in patients without skin inflammation or lesions caused by non-specific chronic abrasion ${ }^{5}$. Although this condition is uncommon, it should not be overlooked. BRP is a clinical condition characterized by chronic pruritus, usually spatially restricted, which differs from most of the other causes of long-term pruritus 6 .

Wallengren and Sundler, studying skin biopsies in 2005, found a reduction in cutaneous sensory innervation during pruritus, which reverse to normal during remissions. These authors found the same results in a similar skin biopsy study after serial phototherapy application ${ }^{7.8}$. However, the methodology used in these studies did not allow to discriminate between myelinated and amyelinated fibers. Even so, the authors classified the sensory involvement as crucial in the pruritus pathophysiology.

Neurological disorders such as notalgia paresthetica and herpes zoster may be associated with pruritus ${ }^{6}$. BRP has been associated with orthopedic/radicular disorders since 1968 and has been studied mainly through image-based

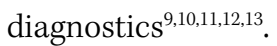

Electroneuromyography (ENMG) has been employed as complementary diagnosis for peripheral nerve lesions, both focal and diffuse, since 1950. It allows to locate the compromised radicular motor nerve to assess the gravity of the process, and avoid a lesion in upper limb peripheral nerves $^{14,15}$. The routine ENMG has limitations in identifying pure sensory radiculopathy. Specifically, ENMG is unable to detect the involvement of amyelinic $\mathrm{C}$ fibers involved in pain and pruritus sensations.

The goal of the present study was to investigate the clinical profile of BRP and to correlate the symptomatic dermatome with the compromised myotomes, using upper limb ENMG in patients with BRP from the Instituto Lauro de Souza Lima (ILSL), Brazil, between 2015 and 2019.

\section{METHODS}

Patients diagnosed with BRP by the ILSL Dermatology Service were referred for evaluations to the ILSL Clinical Neurophysiology between 2015 and 2018. Neurological and ENMG examinations were carried out in every patient. Inclusion criteria were age equal to or higher than 21 years; presence of chronic pruritus ( $>6$-week-long) with characteristic symptoms of BRP, i.e., localized pruritus, no apparent cutaneous lesion, frequently starting bilaterally, and affecting the dorsolateral region of the upper limbs and/or forearms; and negative clinical, laboratorial, and anatomopathological results for other concomitant causes of localized pruritus. Patients with chronic pruritus and skin alterations, with incomplete associated data, or that gave imprecise answers in the interview, were excluded from the analysis.

The patients, after reading and signing a term of consent, were evaluated by the neurophysiology team and the ENMG exam was carried out. A Nihon Kohden MEB-9200J electromyograph was used for the nerve conduction studies (NCS). Following the protocol, studies of motor nerve conduction, sensory, and $\mathrm{F}$ wave were carried out in the upper limb, followed by the electromyography for evaluating the radiculopathy. The sensory NCS analysis were performed distally and antidromically in the Superficial Radialis, Ulnaris V finger and Dorsal Cutaneous Branch, and Median in I-IV digits nerves. Motor conduction were performed in the Ulnar and Median nerves. Both techniques were performed by surface electrodes and the body temperature was controlled between $32-34^{\circ} \mathrm{C}^{16}$. The following muscles were examined: trapezium (C3, C4), deltoid (C5, C6), biceps (C5, C6), triceps (C6, C7, C8), pronator teres or flexor carpi radialis $(\mathrm{C} 6, \mathrm{C} 7)$, extensor indicis or extensor digitorum (C7, C8), first dorsal interossei (C8, $\mathrm{T} 1$ ), and cervical paraspinal muscles.

Chronic neurogenic alterations were considered as such when there were more than $10-25 \%$ polyphasic potentials, i.e., with more than four phases, among the potentials measured in 3-4 sites in each muscle ${ }^{13}$. Radiculopathy is defined by the presence of neurogenic patterns in two or more muscles innervated by the same root belonging to different nerves ${ }^{15}$.

The clinical and neurophysiological results were compared using Pearson's chi-square test considering a 5\% significance level.

\section{RESULTS}

Overall, 46 patients who presented symptoms within the $\mathrm{C} 5-\mathrm{C} 8$ dermatomes were evaluated, totaling 113 
symptomatic dermatomeric areas. The mean age was 60 years (min. 41, max. 83) being 35 women and 11 men, with a mean duration of the disease of five years. Complaints were distributed as follows: 19 cases in C5, 38 in C6, 40 in C7, and 16 in C8, corresponding respectively to $17,34,35$, and $14 \%$ of the symptomatic dermatomeric areas. Signs of radicular involvement were observed in $39(85 \%)$ patients, and in $28(60 \%)$ there was full concordance $(\mathrm{p}=0.015)$ between the complaints and the ENMG findings (Figure 1). When each root was analyzed separately, concordance between dermatological symptoms and ENMG was found in 8 cases at the root of $\mathrm{C} 5,18$ cases in $\mathrm{C} 6,32$ in $\mathrm{C} 7$, and 9 in $\mathrm{C} 8$, representing $7,16,29$, and $8 \%$ of the symptomatic dermatomeric areas, respectively (Figure 2). It was noted that $80 \%$ of the patients with complaints within dermatological territory of C7 $(n=32)$ and $47 \%$ of the patients with complaints in C6 territory $(n=8)$ had signs of radicular involvement at the same level as the ENMG.

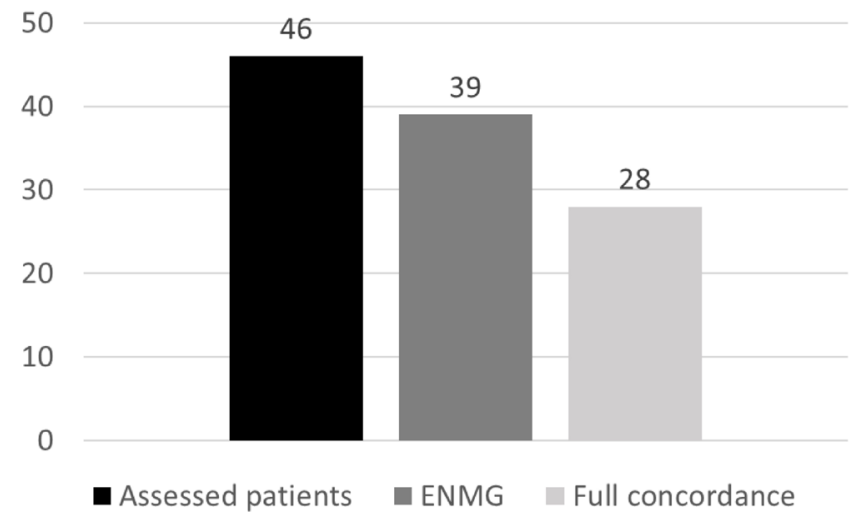

Figure 1. Patients evaluated with brachioradial pruritus (BRP) (black), with neurophysiological findings (ENMG) of radicular distribution (dark gray), and patients with full concordance between dermatological complaints and neurological findings (light gray).

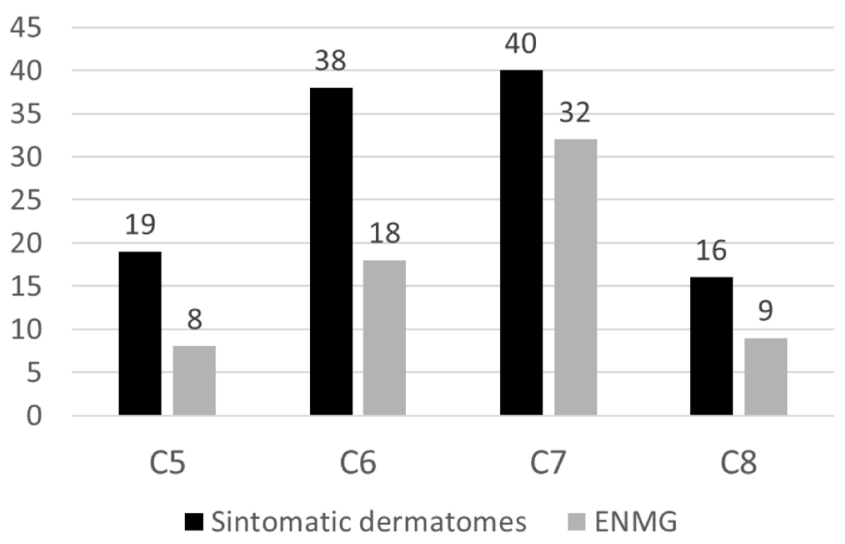

Figure 2. Symptomatic dermatomes (black columns) and miotomeric distribution of the electromyographic alterations (gray columns), classified by nerve root.

\section{DISCUSSION}

The scientific literature shows that the mean age of BRP patients is 59 years, with a predominance in females, which is corroborated by our dataset. Dermatomeric complaints at the roots of $\mathrm{C} 6$ and $\mathrm{C} 7$ were the commonest ones (34 and $35 \%$, respectively) ${ }^{17}$. Considering only the patients with complaints at $\mathrm{C} 7(\mathrm{n}=40), 80 \%$ had electromyographic alterations in myotomeric distribution in $\mathrm{C} 7$.

Pruritus and pain are conducted by the same type of neural fiber, the amyelinic $\mathrm{C}$ fibers, and both have been historically considered different degrees of the same sensation. However, it is currently accepted that pruritus and pain are two distinct mechanisms with great similarity in the transduction of the signals and sharing the same pro-inflammatory mediators, neurotransmitters, and neuropeptides. Both sensations are also processed in the same regions of the brain, i.e., the amygdala, hippocampus, and hypothalamus ${ }^{18}$. Studies of skin biopsy have shown that cutaneous innervation reduces during occurrence of the symptoms ${ }^{7}$. Therefore, these findings suggest the need for a fine and wide assessment of all sensory modalities, including tactile, thermal, pain sensation and autonomic function of the symptomatic areas in pruritus evaluation. In this context, quantitative sensory test (QST) ${ }^{19}$ would be interesting to apply in future neurophysiological studies, which could improve the knowledge on BRP pathophysiology.

Among our sample, individuals with more than 40 years old were more prone to radicular compressions. However, the presence of high frequency of radicular involvement in ENMG in individuals without BRP suggests additional associated causes. In this sense, a hereditary cause was suggested by Wallengren and Dahlbäck, who reported BRP in several members of the same family ${ }^{20}$. Notwithstanding, genome wide association studies were not found in our late literature search.

Some studies report either worsening or beginning of the symptoms after prolonged exposure to sun rays, but it is not known how sun exposure triggers such symptoms ${ }^{8,21}$. Wallengreen suggested that sun exposure could harm nerve endings ${ }^{21}$. The currently accepted etiology is a bicausal origin with cervical radicular involvement and ultraviolet radiation $^{21,22}$. In this study, the C7 dermatome was the most frequently involved, which corresponds to the area more prone to be subjected to sun exposure, i.e., the latero-posterior face (extensor) of the upper limbs.

In conclusion, this study evidences the correlation between cervical radicular involvement and pruritus. The more frequent involvement of the $\mathrm{C} 7$ root, corresponding to the $\mathrm{C} 7$ dermatome, which has more solar exposure, supports the idea that solar radiation is a coadjutant factor in patients with BRP. The majority of patients with cervical radicular involvement did not present pruritus. In order to better recognize this condition (BRP), we suggest future studies aimed at investigating the putative genetic bases of this phenotype. 
1. Wartenberg R. Nerves of the arm: some of their affections; their diagnosis. Cal West Med. 1943 Jul;59(1):22-4.

2. Massey EW, Massey JM. Forearm neuropathy and pruritus. South Med J. 1986 Oct;79(10):1259-60. https://doi.org/10.1097/00007611198610000-00016

3. Waisman M. Solar pruritus of the elbows (brachioradial summer pruritus). Arch Dermatol. 1968 Nov;98(5):481-5. https://doi. org/10.1001/archderm.1968.01610170041006

4. Heyl T. Brachioradial pruritus. Arch Dermatol. 1983 Feb;119(2):115-6. https://doi.org/10.1001/archderm.1983.01650260023009

5. Ständer S, Weisshaar E, Mettang T, Szepietowski JC, Carstens E, Ikoma A, et al. Clinical classification of itch: a position paper of the International Forum for the Study of Itch. Acta Derm Venereol. 2007;87(4):291-4. https://doi.org/10.2340/00015555-0305

6. Weisshaar E, Szepietowski JC, Darsow U, Misery L, Wallengren J, Mettang T, et al. European Guideline on Chronic Pruritus. Acta Derm Venereol. 2012 Sep;92(5):563-81. https://doi.org/10.2340/000155551400.

7. Wallengren J, Sundler F. Brachioradial pruritus is associated with a reduction in cutaneous innervation that normalizes during the symptom-free remissions. J Am Acad Dermatol. 2005 Jan;52(1):1425. https://doi.org/10.1016/j.jaad.2004.09.030

8. Wallengren J, Sundler F. Phototherapy induces loss of epidermal and dermal nerve fibers. Acta Derm Venereol (Stochk). 2004;84:111-5.

9. Goodkin R, Wingard E, Bernhard JD. Brachioradial pruritus: Cervical spine disease and neurogenic/neurogenic pruritus. J Am Acad Dermatol. 2003 Apr;48(4):521-4. https://doi.org/10.1067/ mjd.2003.203

10. Koç B, Boyraz Ï, Özkan H, Yazıcı S, Göksügür N, Sarman H, et al. Brachioradial pruritus: secondary to cervical ependymoma.J PMR Sci. 2015;18:200-3.

11. Crevits L. Brachioradial pruritus - A peculiar neuropathic disorder. Clin Neurol Neurosurg. 2006 Dec;108(8):803-5. https://doi. org/10.1016/j.clineuro.2005.12.001

12. Mataix J, Silvestre JF, Climent JM, Pastor N, Lucas A. Brachioradial pruritus as a symptom of cervical radiculopathy. Actas
Dermosifiliogr. 2008 Nov;99(9):719-22. https://doi.org/10.1016/ s1578-2190(08)70349-4

13. Marziniak M, Phan NQ, Raap U, Siepmann D, Schürmeyer-Horst F, Pogatzki-Zahn E, et al. Brachioradial pruritus as a result of cervical spine pathology: The results of a magnetic resonance tomography study. J Am Acad Dermatol. 2011 Oct;65(4):756-762. https://doi. org/10.1016/j.jaad.2010.07.036

14. Chu SK, Jayabalan P, Visco CJ. McLean EMG Guide, Section III. Needle EMG. 2nd ed. New York, NY: Demosmedical; 2019.

15. Balbinot LF, Garbino JA, Riberto M. Eletroneuromiografia na avaliação das radiculopatias cervicais e lombossacrais. Acta Fisiatr. 2010;17(4):188-92.

16. Preston DC, Shapiro BE. Basic Nerve Conduction Studies. In: Electromyography and Neuromuscular Disorders: ClinicalElectrophysiologic-Ultrasound Correlations. 4th ed. Amsterdam: Elsevier; 2020. p. 23-40

17. Mirzoyev SA, Davis MDP. Brachioradial pruritus: Mayo Clinic experience over the past decade. Br J Dermatol. 2013 Nov;169(5):1007-15. https://doi.org/10.1111/bjd.12483

18. Anzelc M, Burkhart CG. Pain and Pruritus: a study of their similarities and differences. Int J Dermatol. 2020 Feb;59(2):159-64. https://doi. org/10.1111/ijd.14678

19. Schestatsky P, Stefani LC, Sanches PR, Silva Júnior DP, Torres ILS, Dall-Agnol L, et al. Validation of a Brazilian quantitative sensory testing (QST) device for the diagnosis of small fiber neuropathies. Arq Neuropsiquiatr. 2011 Dec;69(6):943-8. https://doi.org/10.1590/ s0004-282x2011000700019

20. Wallengren J, Dahlbäck K. Familial brachioradial pruritus. Br J Dermatol. 2005 Nov;153(5):1016-8. https://doi.org/10.1111/j.13652133.2005.06795.x

21. Wallengren J. Brachioradial pruritus: a recurrent solar dermopathy. J Am Acad Dermatol. 1998 Nov;39(5 Pt 1):803-6. https://doi. org/10.1016/s0190-9622(98)70058-1

22. Robbins BA, Schmieder GJ. Brachioradial pruritus [accessed on Nov 22, 2019]. Available at: https://www.ncbi.nlm.nih.gov/books/ NBK459321/. 